\title{
Manajemen Pembelajaran Pendidikan Anak Usia Dini pada Masa New Normal
}

\author{
Ni Made Krisnanda Kusuma Indra Rini1 ${ }^{*}$, Luh Ayu Tirtayani2 \\ 1,2 Prodi Pendidikan Guru Pendidikan Anak Usia Dini, Universitas Pendidikan Ganesha, Singaraja, Indonesia
}

\section{ART I CLE I N F O}

Article history:

Received July 19, 2021

Revised July 20, 2021

Accepted September 20, 2021

Available online December 25, 2021

Kata Kunci:

Manajemen Pembelajaran, PAUD, New Normal

Keywords:

Learning Management, PAUD, New Normal

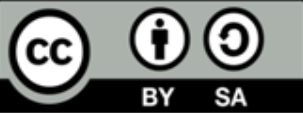

This is an open access article under the CC BY-SA license.

Copyright (C) 2021 by Author. Published by Universitas Pendidikan Ganesha.

\begin{abstract}
A B S T R A K
Perubahan sistem belajar yang dikarenakan situasi pandemi COVID-19 menuju new normal membuat kegiatan belajar mengajar mengalami perubahan pada manajemen pembelajarannya sehingga tenaga pendidik diharuskan menyesuaikan kembali dengan keadaan di masa new normal ini. Penelitian ini bertujuan untuk menganalisis bagaimana manajemen pembelajaran PAUD di masa new normal. Penelitian ini menggunakan rancangan penelitian survei deskriptif dengan pendekatan kuantitatif dengan subjek penelitian ini sebanyak 139 guru dari total populasi sebanyak 213 guru. Pengumpulan data mempergunakan metode non tes dengan instrumen berupa kuesioner tertutup. Tahapan analisis data dalam penelitian ini menggunakan persentase data mean (rata-rata). Hasil penelitian ini dapat dilihat dari aspek perencanaan menunjukkan bahwa perencanaan yang dilakukan oleh guru sudah baik, dari aspek pelaksanaan menunjukkan kegiatan yang dilakukan berjalan dengan lancar, aspek pengawasan menunjukkan persiapan dan strategi yang dirancang sudah sangat baik, kemudian aspek evaluasi menunjukkan segala sesuatunya yang terkait dengan penilaian sudah dirancang dengan sangat baik dan aspek pelaporan menunjukkan segala bentuk pertanggung jawaban guru kepada pihak terkait juga sudah matang. Maka dapat disimpulkan bahwa dalam manajemen pembelajaran PAUD di masa new normal ini dari 5 aspek yang ada menunjukkan hasil yang sangat baik dalam penerapannya.
\end{abstract}

\section{A B S T R A C T}

The change in the learning system due to the COVID-19 pandemic towards the new normal has made teaching, and learning activities change in their learning management so that educators are required to readjust to the conditions in this new normal period. This study aims to analyze PAUD learning management in the new normal period. This study uses a descriptive survey research design with a quantitative approach with the subject of this study as many as 139 teachers from a total population of 213 teachers. Data collection used a non-test method with an instrument in a closed questionnaire. The stages of data analysis in this study used the percentage of the mean (average) data. The results of this study can be seen from the planning aspect indicating that the planning carried out by the teacher is good, from the implementation aspect, it shows that the activities carried out are running smoothly, the supervision aspect shows that the preparation and strategies designed are very good. The evaluation aspect shows that everything related to The assessment has been designed very well, and the reporting aspect shows that all forms of teacher accountability to related parties are also mature. So it can be concluded that the management of PAUD learning in the new normal period from the five existing aspects shows very good results in its application.

\section{PENDAHULUAN}

Pandemi COVID-19 membuat kegiatan di luar rumah yang direncanakan menjadi terhambat, dengan begitu beberapa kegiatan harus dilakukan dari rumah, disamping itu pula ada kebijakan pemerintah untuk membatasi kegiatan yang dilakukan di luar rumah demi mencegah penularan COVID-19 atau Coronavirus (Olonade et al., 2021; Stoecklin et al., 2020; Susilo et al., 2020). Lonjakan kasus positif Covid-19 berdampak pada dunia pendidikan, pemberlakuan kebijakan physical distancing yang kemudian menjadi dasar pelaksanaan belajar di rumah, dengan memanfaatkan teknologi informasi yang berlaku secara tiba- 
tiba, tidak jarang membuat pendidik, siswa, mahasiswa dan orang tua kaget karena belum siap (Lim et al., 2021; Mpungose, 2021; Sohrabi et al., 2020). Keputusan menutup sekolah merupakan keputusan yang sangat berat, dimana suatu aktivitasnya mengurangi kontak secara langsung dengan orang-orang dan juga untuk meminimalisir penyebaran COVID-19 (Alavudeen et al., 2021; Jiang et al., 2021). Prinsip dari kegiatan belajar dari rumah (BDR) ini adalah peserta didik dapat mengakses materi dan sumber pembelajaran tanpa batasan waktu dan tempat. Kegiatan belajar dari rumah (BDR) diharapkan dapat akan mendukung proses pembelajaran jarak jauh dan mempermudah dalam penyebaran materi pembelajaran kepada peserta didik (Dhawan, 2020; Yulianingsih et al., 2020).

Namun permasalahan yang dapat dilihat pada sistem pembelajaran jarak jauh ini dari sisi tenaga pendidik atau guru adalah kurangnya pemahaman siswa ketika melakukan proses pembelajaran daring, kurangnya fasilitas yang dimiliki oleh siswa ketika belajar daring, kuota internet yang tidak bisa dijangkau oleh semua siswa, keterbatasan sinyal dapat menghambat proses belajar mengajar dalam pembelajaran daring dan kondisi peserta didik yang masih tergolong PAUD atau anak usia dini (Hutauruk \& Sidabutar, 2020; Karaeng \& Simanjuntak, 2021; Rigianti, 2020). Pembelajaran jarak jauh yang dilakukan secara daring dalam jangka waktu yang lama memiliki potensi yang negatif terhadap kesehatan psikologi kesehatan mental dan fisik anak dikarenakan, anak tidak memiliki aktivitas di luar rumah (Wang et al., 2020). Lebih lanjut, dijelaskan bahwa penutupan sekolah yang berkepanjangan dan pengurungan dalam rumah selama pandemi sangat berdampak pada fisik dan kesehatan mental anak (Sawitri, 2021). Tanpa disadari karena kondisi yang tidak memungkinkan untuk melakukan kegiatan di luar rumah maka kegiatan anak di masa pandemi COVID-19 sangat terbatas. Dimasa pandemi seperti ini pendidikan karakter yang diarahkan oleh guru di sekolah tidak berjalan optimal (Mujahidin et al., 2021; Windhiyana, 2020). Hal ini karna guru tidak dapat membimbing dan mengarahkan anak secara langsung, melainkan pengarahan dan bimbingan diserahkan pada orang tua anak melalui pembelajaran online. Pembelajaran daring juga memiliki beberapa dampak pada siswa yaitu siswa menjadi kurang bersosialisasi, siswa mengalami kekerasan verbal, kurangnya kedisiplinan dalam pembelajaran di rumah, fasilitas pembelajaran yang tidak memadai, dan tidak tercapai tujuan pembelajaran pada siswa (Fadlilah, 2020; Sutarna et al., 2021). Anak usia dini yang melaksanakan pembelajaran daring dalam jangka waktu yang lama juga sangat.

Menyikapi hal tersebut kebijakan new normal dan himbauan pemerintah tentang hidup berdampingan dengan virus di masa pandemi tidak akan berlangsung dengan cepat untuk menjadi normal kembali dalam melaksanakan aktivitas dari berbagai sigmen kehidupan, terutama dalam melaksanakan aktivitas di bidang pendidikan yang mana melibatkan peserta didik dan tenaga kependidikan (Muhyiddin, 2020; Pragholapati, 2020; Rauf et al., 2021). Maka dari itu, pemerintah mengambil kebijakan dengan menerapkan new normal serta memberikan himbauan kepada masyarakat yang mengharuskan beraktivitas sesuai dengan protokol kesehatan. Kebijakan tentang new normal oleh pemerintahan memiliki pengaruh yang besar bagi aspek bidang kehidupan. Salah satunya yaitu pada bidang pendidikan yang pengaruhnya terdapat dalam pengelolaan sekolah dan peserta didik menuju new normal, dalam hal ini baik guru maupun peserta didik dituntut agar bisa menggunakan teknologi (Andarwulan et al., 2021; Sit \& Assingkily, 2020). Pada saat keadaan sebelum pandemi menuju new normal cara guru menilai kualitas anak yaitu berdasarkan satu kelas, dan pada era new normal nantinya guru tidak bisa menilai dengan cara yang sama seperti dahulu, melainkan ada cara yang lain untuk menilai peserta didiknya yaitu dengan cara memperhatikan peserta didik satu persatu (Cahyadi, 2020; Dziuban et al., 2018). Adapun tujuannya yaitu untuk menggali potensi dari masing-masing peserta didik. Pada penerapan sistem new normal tentunya saat melaksanakan kegiatan belajar tidak akan sama seperti sebelumnya, dengan begitu kegiatan belajar yang dilakukan peserta didik maupun tenaga pendidik dibantu dengan aplikasi-aplikasi penunjang kegiatan belajar seperti aplikasi zoom, whatsapp, google classroom, etmodo maupun aplikasi lainnya (Ayuni et al., 2021; Paramita \& Putra, 2020; Shaleh \& Anhusadar, 2021). Memasuki era "New Normal" pembelajaran pastinya juga kembali normal, pembelajaran juga berlangsung di sekolah. Namun tentunya diperlukan penataan ulang dalam sistem pembelajarannya seperti memadukan penerapan pembelajaran tatap muka langsung, pembelajaran luring, pembelajaran daring serta tetap mengindahkan protokol kesehatan (Eryadini et al., 2020; Sit \& Assingkily, 2020).

Manajemen dalam dunia pendidikan ada banyak jenisnya. Manajemen terdiri dari manajemen Taman Kanak-kanak atau sekolah, manajemen pembelajaran, manajemen kesiswaan, manajemen keuangan, manajemen kepegawaian, manajemen sarana dan prasarana serta manajemen hubungan masyarakat (Bafadal, 2012; Mustafa et al., 2018). Manajemen pembelajaran bagi pendidikan anak usia dini meliputi: standar isi, proses dan penilaian meliputi struktur program, alokasi waktu, dan perencanaan, pelaksanaan, penilaian dilaksanakan secara terintegrasi/terpadu sesuai dengan tingkat perkembangan, bakat/minat dan kebutuhan anak. Perencanaan program dilakukan oleh pendidik yang mencakup tujuan, isi, dan rencana pengelolaan program yang disusun dalam Rencana Kegiatan Mingguan dan Rencana Kegiatan Harian (Dista, 2020; Safitri et al., 2020). Dalam suatu pelaksanaan program pembelajaran agar 
lebih efektif tentunya memerlukan suatu manajemen pembelajaran, dimana manajemen pembelajaran ini bertujuan untuk menciptakan suatu proses belajar mengajar dengan mudah direncanakan, diorganisasikan, dilaksanakan dan dikendalikan dengan baik (Aryantini et al., 2018; Yunita et al., 2019).

Pembelajaran dari rumah perlu manajemen yang tepat yaitu memberikan pengalaman yang bermakna bagi anak tanpa terbebani tuntutan menuntaskan seluruh capaian kurikulum untuk kenaikan kelas ataupun kelulusan (Bafadal, 2012; Mustafa et al., 2018; Winanti et al., 2021). Selain itu manajemen pembelajaran bagi anak usia dini dirancang, dilaksanakan, dan dievaluasi dengan tujuan untuk meningkatkan kualitas pembelajaran (Safitri et al., 2020). Berdasarkan uraian yang telah dipaparkan, maka tujuan penelitian ini yaitu menganalisis bagaimana manajemen pembelajaran PAUD di masa new normal.

\section{METODE}

Penelitian ini menggunakan jenis penelitian survei deskriptif dengan pendekatan kuantitatif. Penelitian survei ini dilakukan untuk memberikan gambaran secara mendetail mengenai latar belakang, karakteristik yang khas dari kasus atau kejadian suatu hal yang bersifat umum. Metode survei dirasa tepat digunakan karena peneliti ingin mengambil data pada banyak responden dan metode ini tidak memerlukan waktu yang lama. Penggunaan metode survei untuk mempermudah peneliti melaksanakan penelitian dengan menjelaskan penelitian yang akan dilaksanakan sebagai cara ilmiah untuk mendapatkan data dengan tujuan dan kegunaan tertentu. Adapun penelitian yang ingin diteliti adalah mengenai penerapan manajemen pembelajaran PAUD pada masa new normal di Kecamatan Kuta Utara. Analisis penelitian ini menggunakan statistik deskriptif mendeskripsikan atau menggambarkan data yang telah terkumpul sebagaimana adanya tanpa bermaksud membuat kesimpulan yang berlaku untuk umum atau generalisasi. Dalam penelitian deskriptif ini digunakan untuk menganalisis penerapan manajemen pembelajaran PAUD pada masa new normal di Kecamatan Kuta Utara dan diolah menggunakan pendekatan kuantitatif. Populasi yang digunakan adalah seluruh guru PAUD di Kecamatan Kuta Utara yang berjumlah 213 guru PAUD. Adapun teknik sampling yang digunakan dalam penentuan sampel yang digunakan adalah proporsional random sampling untuk memberikan setiap anggota populasi (guru) dengan kesempatan yang sama untuk dipilih sebagai sampel. Penentuan sampel dilakukan dengan cara perhitungan statistik yaitu dengan menggunakan Rumus Slovin. Dalam penelitian ini, untuk mempersempit populasi yaitu jumlah guru PAUD di Kecamatan Kuta Utara sebanyak 213 guru dengan menghitung ukuran sampel yang dilakukan dengan menggunakan teknik Slovin. Taraf presisi yang akan digunakan dalam penelitian ini yaitu 5\%.

Metode pengumpulan data yang digunakan dalam penelitian ini yaitu menggunakan metode nontes dengan jenis penyebaran kuisioner/angket. Instrument yang digunakan dalam penelitian ini yakni menggunakan kusioner dengan jenis kuisioner tertutup. Penyebaran kusioner dilakukan dengan bantuan google form. Kusioner yang disebarkan memuat tentang manajemen pembelajaran PAUD yang terdiri dari aspek perencanaan, pelaksanaan, pengawasan, evaluasi dan pelaporan. Pemilihan jawaban dari kuisioner yang telah dibuat menggunakan penskoran dengan skala likert yaitu dengan rentang skor 1 sampai dengan 4. Adapun kisi-kisi instrumen penelitian manajemen pembelajaran PAUD ini disajikan pada Tabel 1.

Tabel 1. Kisi - kisi kuesioner penelitian manajemen pembelajaran PAUD pada masa New Normal

\begin{tabular}{|c|c|c|c|c|}
\hline \multirow{2}{*}{ Variabel } & \multirow{2}{*}{ Komponen } & \multirow{2}{*}{ Indikator } & \multicolumn{2}{|c|}{ Nomor Soal } \\
\hline & & & $(+)$ & $(-)$ \\
\hline Manajemen & Perencanaan & 1. Silabus & 1,2 & \\
\hline \multirow{13}{*}{ Pembelajaran } & & 2. $\mathrm{RPP}$ & 3 & 4 \\
\hline & & 3. Bekerjasama dengan kepala sekolah & 5,6 & \\
\hline & & 4. Bekerja sama dengan sesama guru & 8 & 7 \\
\hline & & 5. Bekerja sama menyesuaikan jadwal & 9 & 10 \\
\hline & Pelaksanaan & 1. Pemberian apersepsi dan motivasi & 11 & 12 \\
\hline & & 2. Penyampaian materi pembelajaran & $13,14,15$ & - \\
\hline & & 3. penyampaian tujuan pembelajaran & 16 & 17 \\
\hline & & $\begin{array}{l}\text { 4. Rangkuman pembelajaran dan tindak } \\
\text { lanjut }\end{array}$ & $18,19,20$ & - \\
\hline & Pengawasan & $\begin{array}{l}\text { 1. Penyusunan laporan hasil-hasil } \\
\text { pengawasan }\end{array}$ & 21 & - \\
\hline & & $\begin{array}{l}\text { 2. Menindaklanjuti untuk perbaikan program } \\
\text { pengawasan pembelajaran }\end{array}$ & 22 & - \\
\hline & Evaluasi & 1. Sistem penilaian & 23,24 & - \\
\hline & & 2. Bentuk soal penilaian pembelajaran & 25,26 & - \\
\hline & & 3. Jenis penilaian & 27,28 & - \\
\hline
\end{tabular}




\begin{tabular}{|c|c|c|c|c|}
\hline \multirow{4}{*}{ Variabel } & \multirow{2}{*}{\begin{tabular}{|c|c|} 
Komponen \\
Pelanoran
\end{tabular}} & \multirow{2}{*}{ Indikator } & \multicolumn{2}{|c|}{ Nomor Soal } \\
\hline & & & $(+)$ & $(-)$ \\
\hline & Pelaporan & 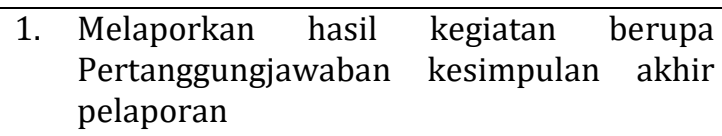 & 29 & - \\
\hline & & 2. Dokumentasi kegiatan & 30 & - \\
\hline
\end{tabular}

Untuk memastikan kualitas dari instrumen yang digunakan memiliki kualitas yang baik dan layak untuk digunakan, maka dilakukan uji validitas instrument dengan melakukan uji validitas isi oleh para ahli yang membidangi topik instrumen yang digunakan (judgment experts). Jumlah ahli yang dilibatkan dalam melakukan uji validitas isi berjumlah 2 orang. Dari hasil perhitungan validitas isi yang telah dilakukan terhadap 30 butir pernyataan dalam angket Manajemen Pembelajaran PAUD, diperoleh koefisien validitas isi 1,00 dan termasuk kriteria validitas isi sangat tinggi. Selanjutnya, setelah dilakukan penyebaran kuisioner data yang telah dikumpulkan dianalisis dengan menggunakan metode analisis statistik deskriptif kuantitatif. Metode analisis statistik deskriptif kuantitatif digunakan untuk mengolah data dari hasil penyebaran instrumen penelitian untuk mendapatkan suatu kesimpulan. Data yang dikumpulkan berupa skor hasil penyebaran kusioner, kemudian dianalisis dengan teknik analisis statistik deskriptif yang terdiri dari menghitung mean dan persentase.

\section{HASIL DAN PEMBAHASAN}

\section{Hasil}

Pelaksanaan penelitian yang bertempat di PAUD se-Kecamatan Kuta Utara bertujuan untuk mengetahui manajemen pembelajaran PAUD di masa new normal . Guna untuk mengetahui bagaimana manajemen pembelajaran PAUD di masa new normal yang diterapkan oleh para guru PAUD di Kecamatan Kuta Utara. Berdasarkan hasil olah data yang telah diuraikan dari penelitian survei manajemen pembelajaran PAUD pada masa new normal di Kecamatan Kuta Utara yang meliputi 5 komponen manajemen pembelajaran pada kisi-kisi instrumen antara lain perencanaan pembelajaran, pelaksanaan pembelajaran, pengawasan pembelajaran, evaluasi pembelajaran dan pelaporan pembelajaran. Deskripsi data yang dipaparkan pada penelitian ini adalah hasil data mengenai manajemen pembelajaran PAUD pada masa new normal. Data perencanaan pembelajaran didapatkan dari penyebaran angket yang berjumlah 10 butir yang bersumber dari 5 indikator dengan 4 pilihan jawaban dari 139 orang guru sebagai responden. Berdasarkan hasil analisis data, responden yang menyatakan sangat sesuai mengenai perencanaan pembelajaran sebesar $55 \%$. Serta sebesar $45 \%$ orang responden yang menyatakan perencanaan pembelajaran sesuai, dan tidak ada responden yang menyatakan tidak sesuai terhadap pernyataan mengenai perencanaan pembelajaran. Data pelaksanaan pembelajaran didapatkan dari penyebaran angket yang berjumlah 10 butir yang bersumber dari 4 indikator dengan 4 pilihan jawaban dari 139 orang guru sebagai responden.

Sebesar $60 \%$ responden yang menyatakan sangat sesuai mengenai pelaksaanaan pembelajaran. Serta sebesar $39 \%$ orang responden yang menyatakan pelaksanaan pembelajaran sesuai, $1 \%$ responden yang menyatakan tidak sesuai terhadap pernyataan mengenai pelaksanaan pembelajaran dan tidak ada yang menyatakan sangat tidak sesuai. Data pengawasan pembelajaran didapatkan dari penyebaran angket yang berjumlah 2 butir yang bersumber dari 2 indikator dengan 4 pilihan jawaban dari 139 orang guru sebagai responden. Sebesar $52 \%$ responden yang menyatakan sangat sesuai mengenai pengawasan pembelajaran. Serta sebesar $46 \%$ responden yang menyatakan pelaksanaan pembelajaran sesuai, $1 \%$ responden yang menyatakan tidak sesuai terhadap pernyataan mengenai pengawasan pembelajaran dan tidak ada yang menyatakan sangat tidak sesuai. Data pelaksanaan pembelajaran didapatkan dari penyebaran angket yang berjumlah 6 butir yang bersumber dari 3 indikator dengan 4 pilihan jawaban dari 139 orang guru sebagai responden. Sebesar $63 \%$ responden yang menyatakan sangat sesuai mengenai evaluasi pembelajaran. Serta sebesar $36 \%$ responden yang menyatakan evaluasi pembelajaran sesuai, $1 \%$ responden yang menyatakan tidak sesuai terhadap pernyataan mengenai evaluasi pembelajaran dan tidak ada yang menyatakan sangat tidak sesuai. Data pelaporan pembelajaran didapatkan dari penyebaran angket yang berjumlah 2 butir yang bersumber dari 2 indikator dengan 4 pilihan jawaban dari 139 orang guru sebagai responden. Data dari hasil perhitungan presentase jawaban responden keseluruhan pelaporan pembelajaran PAUD di Kecamatan Kuta Utara disajikan dalam grafik histogram pada gambar 1. 


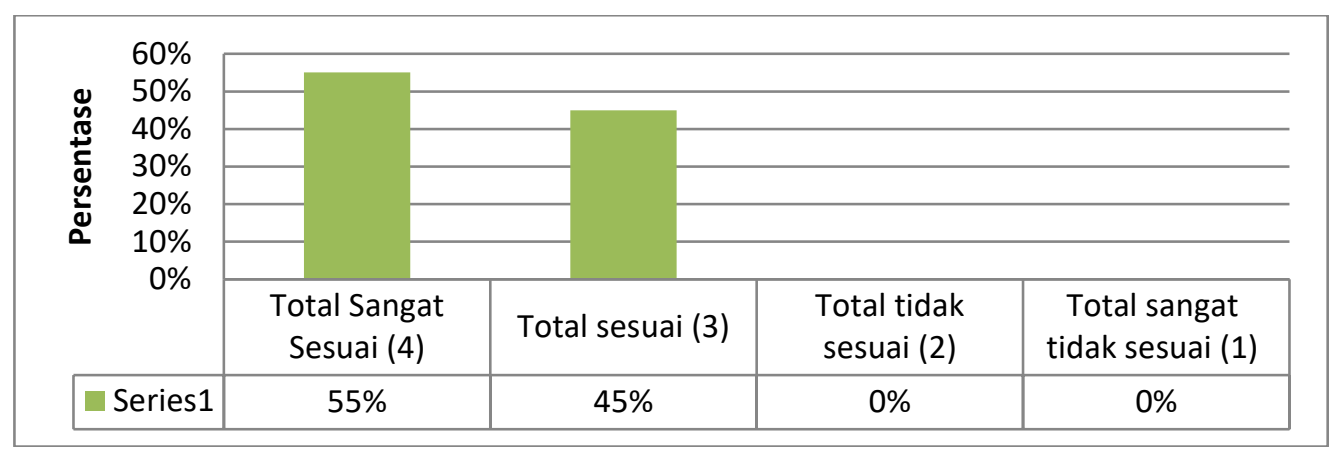

Gambar 1. Histogram Persentase Kriteria Jawaban Responden Keseluruhan Pelaporan Pembelajaran

Hal ini menunjukkan bahwa sebesar 55\% responden yang menyatakan sangat sesuai mengenai pelaporan pembelajaran. Serta sebesar $45 \%$ responden yang menyatakan pelaksanaan pembelajaran sesuai, dan tidak ada yang menyatakan tidak sesuai dan yang menyatakan sangat tidak sesuai pada pernataan mengenai pelaporan pembelajaran.

\section{Pembahasan}

Perencanaan pembelajaran merupakan komponen dari manajemen pembelajaran sebagai proses manajerial dalam menentukan apa yang akan dikerjakan dan bagaimana mengerjakannya. Berdasarkan data yang didapat dari survei manajemen pembelajaran PAUD pada masa new normal di Kecamatan Kuta Utara, diketahui bahwa responden menyatakan sangat sesuai terhadap pernyataan pada komponen perencanaan pembelajaran. Beberapa responden memilih sangat sesuai dilatar belakangi oleh alasan mereka bahwa pernyataan pada komponen perencanaan pembelajaran memang harus selalu direncanakan seperti yang sudah dipaparkan pada kuisioner dan menurut mereka perencanaan pembelajaran merupakan hal yang sangat penting karena dalam perencanaan berisikan tujuan yang harus dicapai, strategi untuk mencapai tujuan pembelajaran, apa saja pendukung-pendukungnya dan lain sebagainya. Perencanaan pembelajaran yang berorientasi pada kebutuhan dan karakteristik anak usia dini, perencanaan sebagai tahap awal dalam proses manajemen menjadi sangat penting karena dengan perencanaan pembelajaran yang tepat dapat memberikan arah yang tepat pula dalam kegiatan pelaksanaan pembelajaran (Dewi, 2017; Iskandar, 2014; Saguni, 2013). Adapun perencanaan pembelajaran yang dipersiapkan oleh guru meliputi pembuatan RPPH, pengelolaan kelas, mempersiapkan media yang dibutuhkan. Perencanaan adalah serentetan program kegiatan yang akan dikerjakan selama waktu tertentu untuk memenuhi target yang diharapkan (Astuti \& Muslim, 2018; Nurhayati, 2018; Sum et al., 2020). Perencanaan pembelajaran disusun untuk memberikan panduan dalam mempersiapkan kegiatan pembelajaran sesuai dengan kemampuan anak dan tahap perkembangan anak untuk mencapai tujuan pembelajaran yang telah direncanakan (Fitri et al., 2017; Ita, 2018; Sufiati \& Afifah, 2019).

Pelaksanaan pembelajaran juga merupakan bagian dari komponen manajemen pembelajaran sebagai proses bentuk implementasi dari perencanaan pembelajaran. Beberapa responden memilih sangat sesuai dilatar belakangi oleh alasan mereka bahwa pernyataan pada komponen pelaksanaan pembelajaran mengacu pada penerapan pembelajaran yang dilakukan di PAUD saat ini mulai dari memberikan motivasi penjelasan tujuan, penyampaian materi dan merangkum memang diterapkan di PAUD. Pelaksanaan pembelajaran akan sangat bergantung pada bagaimana perencanaan pembelajaran (Asta et al., 2015; Hotimah \& Muhtadi, 2018; Iskandar, 2014). Proses Pelaksanaan pembelajaran sangatlah berpacu pada perencanaan pembelajaran yang sudah dibentuk sebelumnya. Dalam pelaksaaan pembelajaran semua guru ikut andil dalam pelaksanaan pembelajaran (Finefter-Rosenbluh, 2016; Hanifah, 2018; Saiti \& Papadopoulos, 2015). Pelaksanaan pembelajaran yang paling sering dan paling berpengaruh dalam kegiatan pembelajaran yaitu kegiatan perencanaan, pelaksanaan, dan penilaian hasil belajar siswa yang merupa- kan satu kesatuan (Contreras et al., 2020; Low et al., 2019). Dengan kata lain kualitas pembelajaran akan sangat dipengaruhi oleh kualitas perencanaan pembelajaran yang digunakan.

Pengawasan pembelajaran merupakan bagian dari komponen manajemen pembelajaran sebagai suatu upaya untuk memastikan bahwa semua aktivitas pembelajaran yang terlaksana telah sesuai dengan apa yang direncanakan (Crismono, 2017; Nuraeni et al., 2017; Sartika \& Erni Munastiwi, 2019). Berdasarkan data yang didapat beberapa responden memilih sangat sesuai dilatar belakangi oleh alasan pernyataan pada kuisioner menyebutkan tentang penyusunan laporan hasil pengawasan dan menindaklanjuti untuk program perbaikan sudah dirasa sesuai. Pengawasan pembelajaran itu sangat diperlukan agar perencanaan yang sudah direncanakan dapat terrealisasi dengan baik karena tujuan dari adanya pengawasan ini adalah untuk mengawasi keadaan di lapangan sehingga jika terjadi permasalah bisa 
dengan segera untuk ditangani dan program-program pembelajaran yang sudah dirancang dapat berjalan dengan mulus (Contreras et al., 2020; Luciana, 2020; Raynesa, 2019). Kegiatan pengawasan pembelajaran dilakukan untuk menghindari penyimpangan yang terjadi serta melihat bagaimana pelaksanaan pembelajaran berlangsung apakah sudah sesuai dengan rencana pembelajaran sehingga jika terjadi penyimpangan bisa secara langsung mengambil ancang-ancang untuk perbaikan (Bin-Hady \& Abdulsafi, 2019; Nurtanto et al., 2021).

Evaluasi pembelajaran merupakan bagian dari komponen manajemen pembelajaran sebagai proses pengumpulan informasi atau memberikan nilai terhadap tingkatan pencapaian pembelajaran (Lukum, 2015; Pantiwati, 2016; Wicaksono et al., 2020). Berdasarkan data yang didapat dari survei manajemen pembelajaran PAUD pada masa new normal di Kecamatan Kuta Utara, diketahui bahwa responden menyatakan sangat sesuai terhadap pernyataan pada komponen evaluasi pembelajaran. Beberapa responden memilih sangat sesuai dilatar belakangi oleh alasan pernyataan yang sudah dipaparkan merupakan hal yang penting diantaranya memilih sistem penilaian, menentukan bentuk soal dan lain sebagainya dirasa sudah sesuai karna sebagai tenaga pendidik juga perlu memikirkan kemudian merancangnya juga untuk mengevaluasi pembelajaran. Evaluasi itu sebagai penentu keadaan suatu objek dengan menggunakan instrumen yang kemudian dibandingkan dengan patokan untuk kesimpulan (Badu, 2013; Munthe, 2015; Wicaksono et al., 2020). Evaluasi pembelajaran dalam proses pendidikan merupakan bagian penting dari evaluasi pendidikan. Kegiatan evaluasi pada pembelajaran harusnya dilakukan oleh guru untuk memperoleh umpan balik atas pembelajaran yan dilakukan.

Pelaporan pembelajaran merupakan bagian dari komponen manajemen pembelajaran sebagai proses penyampaian informasi atau menjelaskan hasil penilaian terhadap pertumbuhan dan perkembangan anak (Puspayanti, 2018; Suartama, 2010). Berdasarkan data yang didapat dari survei manajemen pembelajaran PAUD pada masa new normal di Kecamatan Kuta Utara, diketahui bahwa responden menyatakan sangat sesuai terhadap pernyataan pada komponen pelaporan pembelajaran. Beberapa responden memilih sangat sesuai dilatar belakangi oleh alasan pelaporan itu wajib dilakukan guna sebagai pertanggungjawaban dari hasil pembelajaran anak yang meliputi tumbuh kembang anak dari pembentukan prilaku maupun kemampuan dasarnya sudah sejauh mana. Pelaporan pembelajaran akan sangat bergantung pada kemampuan guru dalam mengelola dan melaksanakannya (Ardiani et al., 2013; Basri, 2017; Syafi'i, 2021). Sebelum membuat pelaporan, guru melakukan kegiatan pengumpulan data sesuai dengan tujuan yang telah ditetapkan berupa hasil deskripsi guru, hasil karya anak dan lain-lain, tentunya itu disesuaikan dengan alat pengumpul data yang telah ditetapkan dalam perencanaan. Dari data yang diperoleh, maka guru akan mengolahnya serta mendeskripsikan hasil dari pelaksanaan evaluasi sehingga akhirnya akan memperoleh gambaran tentang perkembangan anak atau hal lainnya yang berkaitan dengan pembelajaran di PAUD. Melalui pelaporan orang tua dapat mengetahui kelebihan anak apa serta kekurangannya, berdasarkan hal tersebut jika terjadi penyimpangan bisa langsung ditangani atau ditindaklanjuti oleh pihak yang berkepentingan dalam rangka meningkatkan pertumbuhan dan perkembangan anak (Mulyasa, 2012). Temuan-temuan yang didapatkan dari penelitian ini memberikan implikasi yakni temuan dalam penelitian ini dapat digunakan sebagai kajian maupun tambahan informasi untuk pengembangan penelitian yang berkaitan dengan survey manajemen pembelajaran PAUD pada masa new normal. Selain itu, karena keterbatasan penelitian ini, yang hanya meneliti terkait manajemen pembelajaran PAUD pada masa new normal, penulis merekomendasikan agar penelitian selanjutnya dapat mengkaji dengan variabel yang lebih luas dan juga feedbacknya terhadap kegiatan pembelajaran daring.

\section{SIMPULAN}

Manajemen pembelajaran pendidikan anak usia dini untuk menciptakan proses pembelajaran yang menyenangkan diawali dengan perencanaan. Perencanaan pembelajaran disusun secara bersama-sama dalam satu gugus kecamatan dengan menyesuaikan kelengkapan sarana belajar dan kemampuan guru di sekolah masing-masing. Pelaksanaan pembelajaran dilakukan dengan setting kelas dan mengorganisasikan anak berdasarkan kelompok usia, menggunakan metode yang lebih variatif dan media yang menarik. Evaluasi yang diterapkan menggambarkan potensi anak berupa nilai-nilai agama dan moral, sosial emosional, fisik dan komunikasi, kognitif, bahasa dan seni melalui pengamatan, daftar ceklis, hasil karya, unjuk kerja dan penugasan, sehingga tercapai kualitas pembelajaran bagi anak usia dini.

\section{DAFTAR RUJUKAN}

Alavudeen, S. S., Easwaran, V., Mir, J. I., Shahrani, S. M., Ahmed Mohammed Almodeer Aseeri, A. A., Khan, N. A., \& Asiri, A. A. (2021). The influence of COVID-19 related psychological and demographic variables on the effectiveness of e-learning among health care students in the southern region of Saudi 
Arabia. Saudi Pharmaceutical Journal. https://doi.org/10.1016/j.jsps.2021.05.009.

Andarwulan, T., Al Fajri, T. A., \& Damayanti, G. (2021). Elementary teachers' readiness toward the online learning policy in the new normal era during Covid-19. International Journal of Instruction, 14(3), 771-786. https://doi.org/10.29333/iji.2021.14345a.

Ardiani, N. F. W., Guna, N. A., \& Novitasari, R. (2013). Pembelajaran Tematik Dan Bermakna Dalam Perspektif $\begin{array}{llll}\text { Revisi Taksonomi Bloom. Satya Widya, 29(2), } & \text { 93-107. }\end{array}$ https://doi.org/10.24246/j.sw.2013.v29.i2.p93-107.

Aryantini, Agung, \& Dantes. (2018). Kontribusi Implementasi Manajemen Sekolah Berbasis Nilai-Nilai Kearifan Lokal Tri Hita Karana, Kepemimpinan Pelayan Kepala Sekolah, Budaya Sekolah dan Kepuasan Kerja Terhadap Kinerja Guru di SMP Negeri Kecamatan Sukasada Kabupaten Buleleng. Jurnal Administrasi Pendidikan Indonesia, 9(2), 99-110. https://doi.org/10.23887/japi.v9i2.2757.

Asta, I. K. R., Agung, A., Agung, G., \& Widiana, I. W. (2015). BERPIKIR KRITIS TERHADAP HASIL BELAJAR IPA Universitas Pendidikan Ganesha Berdasarkan penelitian dari United. 1. https://doi.org/10.23887/jjpgsd.v3i1.5637.

Astuti, \& Muslim. (2018). Perencanaan dan Analisis E-Book Interaktif Materi ASEAN. Jurnal Informatika Sunan Kalijaga, 2(3). https://doi.org/10.14421/jiska.2018.23-01.

Ayuni, D., Marini, T., Fauziddin, M., \& Pahrul, Y. (2021). Kesiapan Guru TK Menghadapi Pembelajaran Daring Masa Pandemi Covid-19. Jurnal Obsesi: Jurnal Pendidikan Anak Usia Dini, 5(1). https://doi.org/10.31004/obsesi.v5i1.579.

Badu, S. Q. (2013). Implementasi Evaluasi Model Kirkpatrick Pada Perkuliahan Masalah Nilai Awal Dan Syarat Batas. Jurnal Penelitian Dan Evaluasi Pendidikan, 16, 102-129. https://doi.org/10.21831/pep.v16i0.1108.

Bafadal. (2012). Dasar-dasar Manajemen dan Supervisi Taman Kanak-kanak. PT Bumi Aksara.

Basri, I. (2017). Evaluasi Pembelajaran Sekolah Dasar (SD) Berbasis Pendidikan Karakter dan Multikultural. Jurnal Ilmiah Sekolah Dasar, 1(4), 247. https://doi.org/10.23887/jisd.v1i4.12593.

Bin-Hady, W. R. A., \& Abdulsafi, A. S. T. (2019). How Can I Prepare an Ideal Lesson-Plan? SSRN Electronic Journal, 7(4). https://doi.org/10.2139/ssrn.3434031.

Cahyadi, A. (2020). Covid-19 Outbreak and New Normal Teaching in Higher Education: Empirical Resolve from Islamic Universities in Indonesia. Dinamika Ilmu, 20(2), 255-266. https://doi.org/10.21093/di.v20i2.2545.

Contreras, K., Arredondo, C., Díaz, C., Inostroza, M. J., \& Strickland, B. (2020). Examining differences between pre- and in-service teachers' cognition when lesson planning. System, 91. https://doi.org/10.1016/j.system.2020.102240.

Crismono, P. C. (2017). Pengaruh Outdoor Learning Terhadap Kemampuan Berpikir Kritis Matematis Siswa The Influence Of Outdoor Learning On The Mathematical Critical Thinking Skills Of Students. Junal Pendidikan Matematika Dan Sains, 4(2), 106-113. https://doi.org/10.21831/jpms.v5i2.15482.

Dewi, C. (2017). Peningkatan Keterampilan Berbicara Dalam Bermain Drama Melalui Model Pembelajaran Kooperatif Tipe Inside-Outside Circle. Jurnal Inovasi Pembelajaran, 3(2). https://doi.org/https://doi.org/10.22219/jinop.v3i2.4575.

Dhawan, S. (2020). Online Learning: A Panacea in the Time of COVID-19 Crisis. Journal of Educational Technology Systems, 49(1), 5-22. https://doi.org/10.1177/0047239520934018.

Dista. (2020). Manajemen Pendirian Taman Kanak-Kanak (Studi Kasus Di TK Fastrack Funschool Yogyakarta). Jurnal Pendidikan Anak Usia Dini Undiksha, 8(2), 101-111. https://doi.org/10.23887/paud.v8i2.22582.

Dziuban, Graham, C. R., Moskal, P. D., Norberg, A., \& Sicilia, N. (2018). Blended Learning: The New Normal and Emerging Technologies. International Journal of Educational Technology in Higher Education, 15(3), 1-16.

Eryadini, N., Nafisah, D., Sidi, A., \& Buana-lamongan, U. P. A. (2020). Psikologi Belajar Dalam Penerapan Distance Learning. Jurnal Pendidikan Dan Pengabdian Masyarakat, 3(3), 163-168. https://doi.org/10.31004/basicedu.v5i4.1051.

Fadlilah, A. N. (2020). Strategi Menghidupkan Motivasi Belajar Anak Usia Dini Selama Pandemi COVID-19 melalui Publikasi. Jurnal Obsesi: Jurnal Pendidikan Anak Usia Dini, 5(1), 373. https://doi.org/10.31004/obsesi.v5i1.548.

Finefter-Rosenbluh, I. (2016). Behind the scenes of reflective practice in professional development: A glance into the ethical predicaments of secondary school teachers. Teaching and Teacher Education, 60. https://doi.org/10.1016/j.tate.2016.07.028.

Fitri, Saparahayuningsih, \& Agustriana. (2017). Perencanaan Pembelajaran Kurikulum 2013 Pendidikan Anak Usia Dini. Jurnal Ilmiah Potensia, 2(1). https://doi.org/10.33369/jip.2.1.1-13.

Hanifah, H. (2018). Penerapan Manajemen Program Pembelajaran Bagi Guru Paud Dalam Meningkatkan 
Kinerja Pendidik. Comm-Edu (Community Education Journal), 1(3), 24. https://doi.org/10.22460/comm-edu.v1i3.1102.

Hotimah, H., \& Muhtadi, A. (2018). Pengembangan multimedia pembelajaran interaktif IPA untuk meningkatkan pemahaman siswa pada materi Mikroorganisme SMP. Jurnal Inovasi Teknologi Pendidikan, 4(2), 201-213. https://doi.org/10.21831/jitp.v4i2.15047.

Hutauruk, A., \& Sidabutar, R. (2020). Kendala pembelajaran daring selama masa pandemi di kalangan mahasiswa pendidikan matematika: Kajian kualiatatif deskriptif. Journal of Mathematics Education and Applied, 02(01), 45-51. https://doi.org/10.36655/sepren.v2i1.364.

Iskandar, S. M. (2014). Pendekatan Keterampilan Metakognitif Dalam Pembelajaran Sains Di Kelas. Erudio Journal of Educational Innovation, 2(2), 13-20. https://doi.org/10.18551/erudio.2-2.3.

Ita, E. (2018). Manajemen pembelajaran pendidikan anak usia dini di TK Rutosoro Kecamatan Golewa Kabupaten Ngada Flores Nusa Tenggara Timur. Jurnal Dimensi Pendidikan Dan Pembelajaran, 6(1), 45-52. https://doi.org/10.24269/dpp.v6i1.889.

Jiang, H., Islam, A. Y. M. A., \& Gu, X. et al. (2021). Online learning satisfaction in higher education during the COVID-19 pandemic: A regional comparison between Eastern and Western Chinese universities. Educ Inf Technol, 1(1). https: //doi.org/10.1007/s10639-021-10519-X..

Karaeng, L. K. G., \& Simanjuntak, D. C. (2021). EXPLORATION OF EFL TEACHERS 'EXPERIENCE TOWARD THE IMPLEMENTATION OF E-LEARNING AMIDST THE COVID-19 PANDEMIC: A QUALITATIVE INTERVIEW STUDY. 4(2), 324-340. https://doi.org/10.22460/project.v4i2.p324-340.

Lim, M. T. C., Ramamurthy, M. B., Aishworiya, R., Rajgor, D. D., Tran, A. P., Hiriyur, P., Kunaseelan, S., Jabri, M., \& Goh, D. Y. T. (2021). School closure during the coronavirus disease 2019 (COVID-19) pandemic - Impact on children's sleep. Sleep Medicine, 78(January 2020), 108-114. https://doi.org/10.1016/j.sleep.2020.12.025.

Low, E. L., Ng, P. T., Hui, C., \& Cai, L. (2019). How do teacher affective and cognitive self-concepts predict their willingness to teach challenging students? Australian Journal of Teacher Education, 44(10), 18-34. https://doi.org/10.14221/ajte.2019v44n10.2.

Luciana, N. L. R. (2020). Teachers' Readiness in Inserting the 21st Century Skills in the Lesson Plan in Teaching English. Jurnal Pendidikan Dan Pengajaran, 53(2), 168. https://doi.org/10.23887/jpp.v53i2.26406.

Lukum, A. (2015). Evaluasi Program Pembelajaran Ipa Smp Menggunakan Model Countenance Stake. Jurnal Penelitian Dan Evaluasi Pendidikan, 19(1), 25-37. https://doi.org/10.21831/pep.v19i1.4552.

Mpungose, C. B. (2021). Lecturers' reflections on use of Zoom video conferencing technology for e-learning at a South African university in the context of coronavirus. African Identities. https://doi.org/10.1080/14725843.2021.1902268.

Muhyiddin. (2020). Covid-19, New Normal, dan Perencanaan Pembangunan di Indonesia. Jurnal Perencanaan Pembangunan: The Indonesian Journal of Development Planning, 4(2), 240-252. https://doi.org/10.36574/jpp.v4i2.118.

Mujahidin, E., Mangunjaya, F. M., \& Wibowo, R. (2021). The Impact and Strategy for Combating the Outbreak Covid-19 in Student. 5(4), 2145-2155. https://doi.org/10.31004/basicedu.v5i4.1057

Mulyasa, H. E. (2012). Manajemen PAUD. PT Remaja Rosdakarya..

Munthe, A. P. (2015). Pentingya Evaluasi Program Di Institusi Pendidikan: Sebuah Pengantar, Pengertian, Tujuan dan Manfaat. Scholaria: Jurnal Pendidikan Dan Kebudayaan, 5(2), 1. https://doi.org/10.24246/j.scholaria.2015.v5.i2.p1-14.

Mustafa, Murniati, \& Niswanto. (2018). Manajemen Sarana Pendidikan Pada Sekolah Anak Berkebutuhan Khusus Di SDLB YTC Kutablang Kabupaten Bireuen. Jurnal Administrasi Pendidikan, 6(1).

Nuraeni, D., Utaya, S., \& Akbar, S. (2017). Aktivitas Belajar Dalam Pembelajaran Inside Outside Circle Melalui Lesson Study Pada Kelas V SD. Jurnal Pendidikan: Teori, Penelitian, Dan Pengembangan, 2(9), 11751181. https://doi.org/10.17977/jptpp.v2i9.9931.

Nurhayati, Y. (2018). Penerapan Model Kirkpatrick untuk Evaluasi Program Diklat Teknis Subtantif Materi Perencanaan Pembelajaran Di Wilayah Kerja Provinsi Kepulauan Riau. Andragogi: Jurnal Diklat Teknis Pendidikan Dan Keagamaan, 6(2), 170-187. https://doi.org/10.36052/andragogi.v6i2.63.

Nurtanto, M., Kholifah, N., Masek, A., Sudira, P., \& Samsudin, A. (2021). Crucial problems in arranged the lesson plan of vocational teacher. International Journal of Evaluation and Research in Education (IJERE), 10(1), 345-354. https://doi.org/10.11591/ijere.v10i1.20604.

Olonade, O. Y., Adetunde, C. O., Iwelumor, O. S., Ozoya, M. I., \& George, T. O. (2021). Coronavirus pandemic and spirituality in southwest Nigeria: A sociological analysis. Heliyon, 7(March), e06451. https://doi.org/10.1016/j.heliyon.2021.e06451.

Pantiwati, Y. (2016). Hakekat Asesmen Autentik Dan Penerapannya Dalam Pembelajaran Biologi. Jurnal Edukasi Matematika Dan Sains, 1(1), 18. https://doi.org/10.25273/jems.v1i1.773. 
Paramita, I. B. G., \& Putra, I. G. G. P. A. (2020). New Normal Bagi Pariwisata Bali Di Masa Pandemi Covid 19. Jurnal Ilmiah Pariwisata Agama Dan Budaya, 5(2). https://doi.org/10.25078/pba.v5i2.1723.

Pragholapati, A. (2020). New Normal "Indonesia" After Covid-19 Pandemic. 2019, 1-6. https://doi.org/10.31234/osf.io/7snqb.

Puspayanti, A. (2018). Evaluasi pembelajaran diklat menggunakan model countenance stake. Andragogi Jurnal Diklat Teknis Pendidikan Dan Keagamaan, 4(1), 143-167. https://doi.org/10.36052/andragogi.v6i1.52.

Rauf, R., Wijaya, H., \& Tari, E. (2021). Entrepreneurship education based on environmental insight: Opportunities and challenges in the new normal era. Cogent Arts \& Humanities, 8(1). https: //doi.org/10.1080/23311983.2021.1945756.

Raynesa. (2019). Lesson Planning in EFL Classroom: A Case Study in Lesson Plan Preparation and Implementation. Wiralodra English Journal, 3(2), 367-375. https: //doi.org/10.31943/wej.v3i2.67.

Rigianti, H. A. (2020). Kendala Pembelajaran Daring Guru Sekolah Dasar di Kabupaten Banjarnegara. Orphanet Journal of Rare Diseases, 21(1), 1-9. https://doi.org/10.31316/esjurnal.v7i2.768.

Safitri, A., Kabiba, K., Nasir, N., \& Nurlina, N. (2020). Manajemen Pembelajaran bagi Anak Usia Dini dalam Meningkatkan Kualitas Pembelajaran. Jurnal Obsesi : Jurnal Pendidikan Anak Usia Dini, 5(2), 12091220. https://doi.org/10.31004/obsesi.v5i2.811.

Saguni, F. (2013). Efektivitas Metode Problem Based Learning, Cooperative Learning Tipe Jigsaw, Dan Ceramah Sebagai Problem Solving Dalam Matakuliah Perencanaan Pembelajaran. Cakrawala Pendidikan, 1(2). https://doi.org/10.21831/cp.v0i2.1478.

Saiti, A., \& Papadopoulos, Y. (2015). School teachers' job satisfaction and personal characteristics: A quantitative research study in Greece. International Journal of Educational Management, 29(1), 7397. https://doi.org/10.1108/IJEM-05-2013-0081.

Sartika, \& Erni Munastiwi. (2019). Peran Guru Dalam Mengembangkan Kreativitas Anak Usia Dini Di TK Islam Terpadu Salsabila Al-Muthi'in Yogyakarta. Golden Age: Jurnal Ilmiah Tumbuh Kembang Anak Usia Dini, 4(2). https: //doi.org/10.14421/jga.2019.42-04.

Sawitri, H. (2021). COVID-19: Tingkat Stres Belajar Anak-Anak faktor dari dalam individu seperti penyakit bawaan yang telah dialami dan kurangnya. 5(2), 101-124. https://doi.org/10.35931/am.v5i2.542.

Shaleh, M., \& Anhusadar, L. (2021). Kesiapan Lembaga PAUD dalam Pembelajaran Tatap Muka pada New Normal. Jurnal Obsesi : Jurnal Pendidikan Anak Usia Dini, 5(2). https://doi.org/10.31004/obsesi.v5i2.1139.

Sit, M., \& Assingkily, M. S. (2020). Persepsi Guru tentang Social Distancing pada Pendidikan AUD Era New Normal. Jurnal Obsesi: Jurnal Pendidikan Anak Usia Dini, 5(2), 1009-1023. https://doi.org/10.31004/obsesi.v5i2.756.

Sohrabi, C., Alsafi, Z., O’Neill, N., Khan, M., Kerwan, A., Al-Jabir, A., ..., \& Agha, R. (2020). World Health Organization Declares Global Emergency: A review of the 2019 Novel Coronavirus (COVID-19). International Journal of Surgery, 76(February), 71-76. https://doi.org/10.1016/j.ijsu.2020.02.034.

Stoecklin, S. B., Rolland, P., Silue, Y., Mailles, A., Campese, C., Simondon, A., Mechain, M., Meurice, L., Nguyen, M., Bassi, C., Yamani, E., Behillil, S., Ismael, S., Nguyen, D., Malvy, D., Lescure, F. X., Georges, S., Lazarus, C., Tabai, A., ... Levy-Bruhl, D. (2020). First cases of coronavirus disease 2019 (COVID-19) in France: Surveillance, investigations and control measures, January 2020. Eurosurveillance, 25(6), 2000094. https://doi.org/10.2807/1560-7917.ES.2020.25.6.2000094.

Suartama, I. K. (2010). Kualitas Pembelajaran Pada Mata Kuliah Media. Jurnal Pendidikan Dan Pengajaran, 43(3), 253-262. https://doi.org/10.23887/jppundiksha.v43i3.130.

Sufiati, V., \& Afifah, S. N. (2019). Peran perencanaan pembelajaran untuk performance mengajar guru pendidikan anak usia dini. Jurnal Pendidikan Anak, 8(1), 48-53. https://doi.org/10.21831/jpa.v8i1.26609.

Sum, T. A., Graciela, E., \& Taran, M. (2020). Jurnal Obsesi : Jurnal Pendidikan Anak Usia Dini Kompetensi Pedagogik Guru PAUD dalam Perencanaan dan Pelaksanaan Pembelajaran Abstrak. 4(2), 543-550. https://doi.org/10.31004/obsesi.v4i2.287.

Susilo, Rumende, Pitoyo, Santoso, Yulianti, Herikurniawan, \& Sinto. (2020). Coronavirus Disease 2019 : Tinjauan Literatur Terkini Coronavirus Disease 2019: Review of Current Literatures. Jurnal Penyakit Dalam Indonesia, 7(1). https://doi.org/10.7454/jpdi.v7i1.415.

Sutarna, N., Acesta, A., Cahyati, N., Giwangsa, S. F., Iskandar, D., \& Harmawati, H. (2021). Dampak Pembelajaran Daring terhadap Siswa usia 5-8 tahun. Jurnal Obsesi : Jurnal Pendidikan Anak Usia Dini, 6(1), 288-297. https://doi.org/10.31004/obsesi.v6i1.1265.

Syafi'i. (2021). Strategi Pelaporan Penilaian Pembelajaran Dalam Masa Pandemi Covid-19 di RA Al-Ma'ruf Beyan. Potensia, Jurnal Ilmiah, 6(1), 57-65. https://doi.org/10.33369/jip.6.1.57-65.

Wang, G., Zhang, Y., Zhao, J., Zhang, J., \& Jiang, F. (2020). Mitigate the effects of home confinement on children 
during the COVID-19 outbreak. The Lancet, 395(10228), 945-947. https://doi.org/10.1016/S0140-6736(20)30547-X.

Wicaksono, P. N., Kusuma, I. J., Festiawan, R., Widanita, N., \& Anggraeni, D. (2020). Evaluasi penerapan pendekatan saintifik pada pembelajaran pendidikan jasmani materi teknik dasar passing sepak bola. Jurnal Pendidikan Jasmani Indonesia, 16(1), 41-54. https://doi.org/10.21831/jpji.v16i1.29774.

Winanti, R., Purwanto, \& Khuriyah. (2021). Model Manajemen Pembelajaran Dari Rumah Untuk Pendidikan Berkarakter ( Studi Pada TK Islam Makarima Dan TK Inklusi Saymara Sukoharjo ). Jurnal Ilmiah Ekonomi Islam, 7(02), 648-660. https://doi.org/10.33394/jp.v7i4.2941.

Windhiyana, E. (2020). Dampak Covid-19 Terhadap Kegiatan Pembelajaran Online Di Perguruan Tinggi Kristen Di Indonesia. Perspektif Ilmu Pendidikan, 34(1), 1-8. https://doi.org/10.21009/pip.341.1.

Yulianingsih, W., Suhanadji, S., Nugroho, R., \& Mustakim, M. (2020). Keterlibatan Orangtua dalam Pendampingan Belajar Anak selama Masa Pandemi Covid-19. Jurnal Obsesi : Jurnal Pendidikan Anak Usia Dini, 5(2), 1138-1150. https://doi.org/10.31004/obsesi.v5i2.740.

Yunita, E. I., Suneki, S., \& Wakhyudin, H. (2019). Manajemen Pendidikan Inklusi dalam Proses Pembelajaran dan Penanganan Guru Terhadap Anak Berkebutuhan Khusus. International Journal Of Elementary Education, 3(3). https://doi.org/10.23887/ijee.v3i3.19407. 